\title{
Cytomixis in Pollen Mother Cells of Urochloa panicoides P. Beauv. (Poaceae)
}

\author{
Basavaiah and T.C.S. Murthy \\ Department of Post-Graduate Studies and Research in Botany, \\ University of Mysore, \\ Manasa Gangotri, Mysore-570 006, India
}

Accepted September 24, 1985

Cytomixis generally refers to the migration of chromatin from one cell to the other through cytoplasmic connections. The phenomenon was first described by Körnicke (1901) in pollen mother cells (PMCs) of Crocus sativus and the term was coined and defined by Gates (1911). It has been reported more commonly during microsporogenesis in a wide range of angiosperms which include genetically unbalanced types such as hybrids (Nettancourt and Grant 1964, Salesses 1970), mutants (Gottschalk 1970, Datta and Biswas 1984), triploids (Salesses 1970, Semyarkhina and Kuptsou 1974), apomicts (Mantu and Sharma 1983) and also in normal diploids (Omara 1976, Morisset 1978). In addition, such migration of chromatin has been reported to occur in mitotic cells (Sarvella 1958, Bowes 1973) and between tapetal cells and PMCs (Cooper 1952). Cytomixis has been induced in the root tip cells of Vicia faba (Bobak and Herich 1978). Although these studies established the phenomenon as a cytological fact, the views regarding its occurrence, cause and significance have been varied and speculative.

The phenomenon of cytomixis has been recorded by Church (1929) in certain members of Poaceae who pointed out that the occurrence of cytomixis in hybrids is very striking. It has been reported in many cereals and their hybrids (vide Kamra 1960). The present investigation records cytomixis for the first time in the genus Urochloa, in $U$. panicoides P. Beauv. The cytological consequences of cytomixis and its significance are also discussed.

\section{Material and methods}

Urochloa panicoides P. Beauv, an annual forage grass of Panicoidae has four morphologically distinct true breeding varieties viz., $U$. panicoides var. panicoides, var. pubescens (Kunth.) Bor, var. marathensis (Henr.) Bor and var. velutina (Henr.) Bor. These are widely distributed in South India (Bor 1960). For a biosystematic study, all these four varieties have been collected from more than 100 sites of South India between July 1982 and July 1984. The clones were raised in botanical garden of the Department.

Young spikes with flowers in pre-anthesis stages were collected between 8 and $10 \mathrm{AM}$ and fixed in $1: 3$ acetic alcohol for $20-24$ hours, transfered to $70 \%$ ethanol and stored at $10^{\circ} \mathrm{C}$. Anthers were squashed in $2 \%$ acetocarmine and meiosis was studied. The spikelets stored in $70 \%$ ethanol were dissected, processed and embedded in paraffin following the customary methods for microtomy. Serial longitudinal sections, $8-12 \mu$ in thickness were cut and stained with Heidenhain's Iron-alum-Haematoxylin. They were mounted with D.P.X. Pollen grains were studied following the differential staining procedure (Alexander 1969).

\section{Observations}

Cytomixis was observed in pollen mother cells at various stages of meiosis in varying 

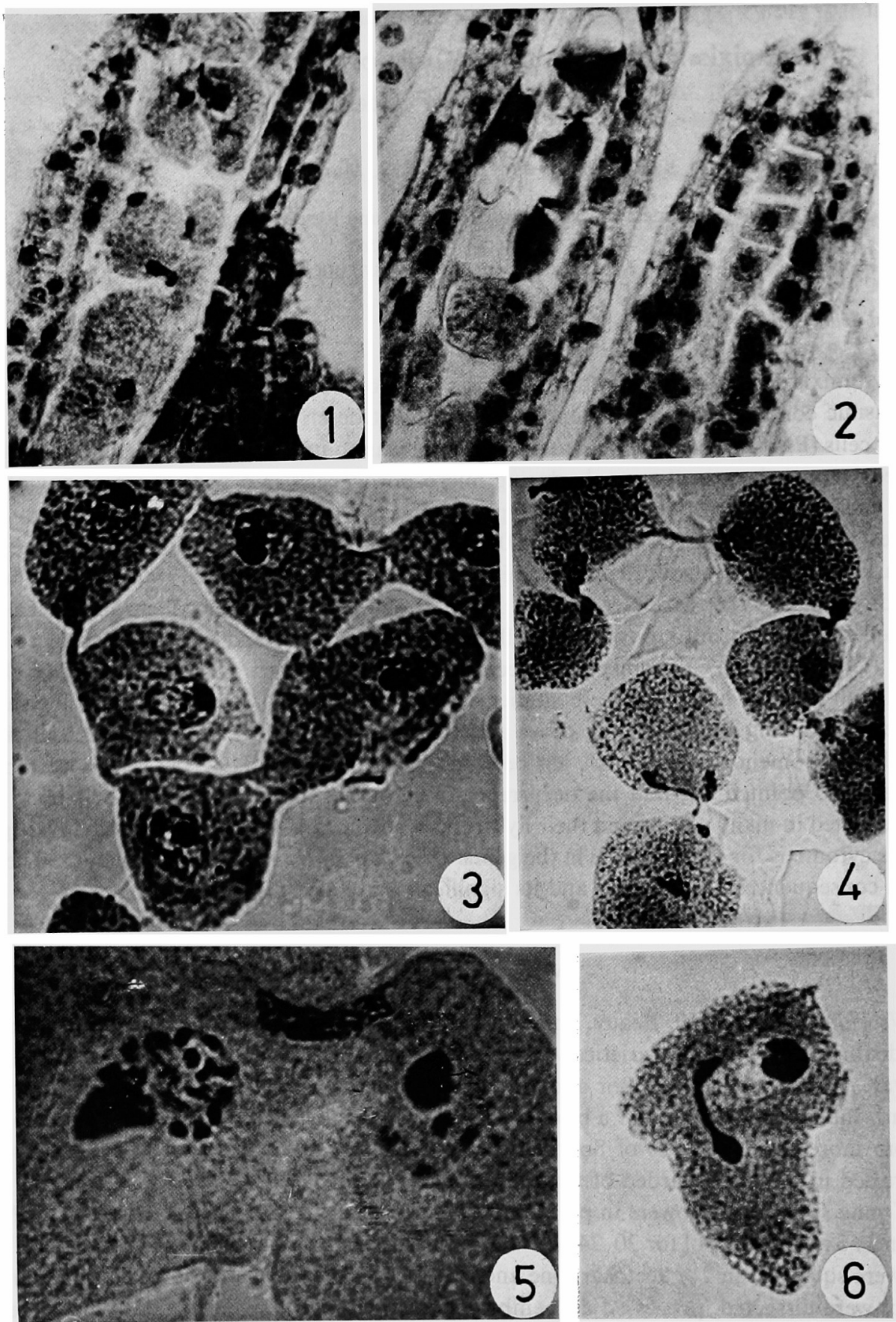

Figs. 1-6. U. panicoides P. Beauv. 1, L. S. of anther with PMCs showing cytomixis. $\times 2700$. 2, L. S. of anther showing one lobe with cytomictic PMCs and the adjacent lobe with normal PMCs $\times 2700.3$, PMCs showing cytoplasmic connections. $\times 3150.4$, PMCs showing cytomixis at early prophase I. $\times 3150$. 5, PMCs showing the movement of a part of the chromatin. $\times 4500$. 6 , PMCs showing the movement of whole chromatin. $\times 2700$. 
percentages in three varieties (var. pubescens, var. marathensis and var. velutina) of $U$.panicoides while the var. panicoides showed only occasional cytoplasmic connections (Table 1). In all the four varieties the chromosome number is $2 n=4 x=48$. Cytomixis was not found throughout the year but was very conspicuous during summer season. It was in highest percentages in robust plants grown by regular manuring in the experimental garden. Its occurrence was also noted in both fixed and fresh spikelets. Serial longitudinal sections of cytomictic anthers showed normal morphological and histological features, but the PMCs exhibited cytomixis (Fig. 1). In some anthers, the cytomixis was restricted to only one lobe of the anther and the remaining lobe exhibited normal division or occasional cytomixis (Fig. 2).

Table 1. Percentages of cytomixis and pollen fertility in the varieties of Urochloa panicoides P. Beauv.

\begin{tabular}{lcccccc}
\hline \hline Variety & $\begin{array}{c}\text { Total } \\
\text { number } \\
\text { of cells } \\
\text { observed }\end{array}$ & $\begin{array}{c}\text { No. of } \\
\text { cells } \\
\text { showing } \\
\text { cytoplasmic } \\
\text { connections }\end{array}$ & $\begin{array}{c}\text { No. of cells showing } \\
\text { cytomixis }\end{array}$ & $\begin{array}{c}\text { Meiosis } \\
\text { I }\end{array}$ & $\begin{array}{c}\text { Meiosis } \\
\text { II }\end{array}$ & $\begin{array}{c}\text { of } \\
\text { cytomixis } \\
\text { pollen } \\
\text { fertility }\end{array}$ \\
\hline var. panicoides & 710 & 33 & - & - & - & 97.6 \\
var. pubescens & 620 & 95 & 49 & 13 & 10 & 94.1 \\
var. marathensis & 860 & 132 & 86 & 17 & 12 & 95.3 \\
var. velutina & 530 & 120 & 79 & 16 & 18 & 92.1 \\
\hline
\end{tabular}
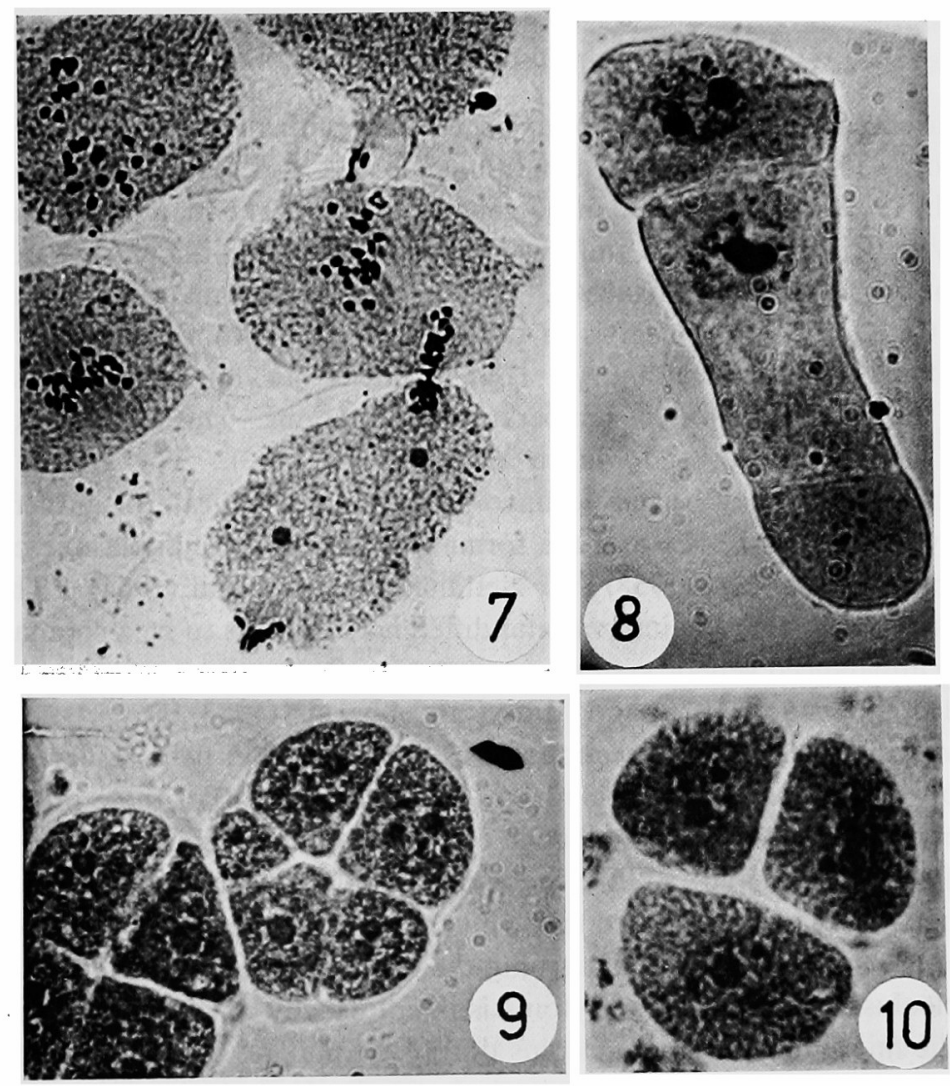

Figs. 7-10. U. panicoides $\mathrm{P}$. Beauv. 7, PMCs at late prophase I showing migrating bivalents, and nucleolus being remained in the donor cell. $\times 2700$. 8, Irregular tetrad. 9, A polyad and a tetrad. 10, A triad. $8-10 \times 3000$. 
It was interesting to note the extensive cytoplasmic connections of varying breadth between meiocytes (Fig. 3) and the formation of syncitial bunches involving 8 to 20 PMCs in all the four varieties of the species. In early prophase I PMCs, the chromatin moves along with the nucleolus synchronously, directed to the area of cytoplasmic connections (Figs. 4, 5). But such synchrony was not apparent at later stages of meiosis and the nucleolus remained in the donor cell (Figs. 6,7). The frequency of cytomixis and the amount of migrating chromatin was reduced as meiosis advanced. PMCs of prophase I showed chromatin migration more frequently than in other stages of meiosis. It was recorded upto metaphase II in var. pubescens and var. marathensis, and upto anaphase II in var. velutina.

The amount of migrating chromatin varied greatly ranging from a portion of it to the entire complement. As a result of this irregular distribution of chromatin, $6 \%$ of PMCs with hypoand hyperploid variations were recorded in diakinesis. The hypoploid PMCs of $2 n-1$ to $2 n-8$ chromosomes were quite frequent whereas in hyperploid PMCs the intruded extra chromatin was not regenerated. Further the consequences of cytomixis at later stages of meiosis were manifested through the formation of incomplete tetrads (Fig. 8), polyads (Fig. 9) and triads (Fig. 10). In addition, tetrad cells with irregular sizes and micronuclei were noticed. Although percentage of viable pollen grains in three cytomictic varieties was quite normal, it was less than those of var. panicoides (Table 1). Seed setting in all the four varieties was normal. Meiotic irregularities like laggards, anaphase bridges, tetravalents and sticky chromosomes were observed occasionally in cytomictic varieties.

\section{Discussion}

The possible causes attributed to cytomixis are action of fixatives (Takats 1959), mechanical injury (Woodworth 1931), pathological conditions (Bobak and Herich 1978), temperature anomalies (Narain 1979) and also unbalanced genetic system of the plant (Morisset 1978). The occurrence of cytomixis both in fixed and fresh spikelets noticed in the present study infers that it is possibly not due to action of fixatives. The presence of normal histological features excepting the PMCs undergoing cytomixis in serial sections of cytomictic anthers demonstrates that it is also not due to mechanical injury. High incidence of cytomixis in plants raised during summer clearly indicates the effect of temperature fluctuations. This is in accordance with the observations of Narain (1979), and Mantu and Sharma (1983). The greater frequency of cytomixis in robust plants may be due to unco-ordinated growth rate of anthers which leads to incomplete cytokinesis in PMCs and the formation of massive cytoplasmic connections as observed in hybrids by Sarvella (1958) and Nettancourt and Grant (1964). Therefore, cytomixis in the present study with the intervarietal differences appears to be a spontaneous process expressed by the unbalanced genetic system in response to fluctuating environmental conditions as also concluded by Omara (1976) and Mantu and Sharma (1983).

The observed intermeiocyte connections in $U$. panicoides can be considered as cytomictic channels (Heslop Harrison 1960). Whelan (1974) has suggested that these intermeiocyte connections may serve as channels in the exchange of cytoplasmic organelles and in extreme cases, the exchange of nuclear material. While inducing cytomixis by the application of trifluraline, Bobak and Herich (1978) have suggested that trifluraline possibly induces cytomixis by influencing the process of cytokinesis and by disturbing the nucleoplasmatic relations among the cells. The role of nucleolus in the process of cytomixis is not exactly known. Bhandari et al. (1969) have reported the migration of only nucleolus during cytomixis. In the present study the nucleolus appears to migrate along with chromatin lumps in the early prophase, but it remained in the donor cell in later stages of cytomixis.

It is generally observed that the frequency of cytomixis invariably reduced as the meiosis 
advanced (Morisset 1978, Mantu and Sharma 1983). Consequently the effects of cytomixis may also vary in early and late stages of meiosis. The consequences of synchronous cytomixis in early prophase cells appears to be mostly degenerative as most of the PMCs of the previous cytomixis were clearly degenerating. This may be due to disturbance in the nucleoplasmatic relations of the meiocytes caused by the migration of partial or complete chromatin complement (Bobak and Herich 1978). Due to migration of few differentiated chromosomes in later stages of meiosis, there may be formation of aneuploid PMCs which differentiate further and may produce aneuploid gametes. Occurrence of aneuploid PMCs at diakinesis, irregular tetrads, triads and polyads indicate the possibility of aneuploid and polyploid gamete production. The significance of cytomixis has been variously assessed. It has been speculated as a possible mechanism of origin of aneuploids (Sarvella 1958, Omara 1976) and B-chromosomes (Cheng et al. 1975). In $U$. panicoides all the four varieties have normal pollen fertility and seed setting. This may be due to the infrequent occurrence of cytomixis in later stages of meiosis. Possibility of variant production through cytomixis appears to be meagre as there are many factors which hinder the transmission of extra chromosomes, like reduced viability and competitive ability of male gametophyte (Omara 1976). Therefore cytomixis appaers to be of less significance in the origin of variants.

\section{Summary}

Cytomixis was recorded during microsporogenesis in three varieties of Urochloa panicoides P. Beauv. (Poaceae) in different percentages as var. pubescens $10 \%$, var. marathensis $12 \%$ and var. velutina $18 \%$, while var. panicoides showed only occasional cytoplasmic connections. It was commonly observed during summer. Also, the robust plants raised in the experimental garden showed highest percentages of cytomixis. The phenomenon was more frequent in prophase I and noted upto anaphase II with decreasing frequencies. The amount of migrating chromatin was also reduced as meiosis advanced. The role of nucleolus was not clear. Cytological analysis of cytomictic plants revealed the formation of upto $6 \%$ of hypo- and hyperploid meiocytes, triads, irregular tetrads and polyads.

The seasonal occurrence and the intervarietal differences in the frequencies of cytomixis demonstrates that it is the expression of unbalanced genetic system of plants in response to environmental conditions. The pollen fertility and seed setting was not affected by this process indicating that the phenomenon is not of much significance.

\section{Acknowledgements}

Senior author is thankful to the University Grants Commission, New Delhi for the award of a Research Fellowship. Thanks are also due to Dr. M. Muniyamma, Reader, Department of Botany, University of Mysore, Mysore for facilities and helpful suggestions.

\section{References}

Alexander, M. P. 1969. Differential staining of aborted and non-aborted pollen. Stain Technol. 44 (3): 117122.

Bhandari, N. N., Tandon, S. L. and Jain, S. 1969. Some observation on the cytology and cytomixis in Canavalia DC. Cytologia 34: 22-28.

Bobak, M. and Herich, R. 1978. Cytomixis as a manifestation of pathological changes after the application of triffuraline. The Nucleus $20(1): 22-26$.

Bor, N. L. 1960, The Grasses of Burma, Ceylon, India and Pakistan, Pergaman Press, Oxford.

Bowes, B. G. 1973. Note on apparent case of cytomixis in the root apex of Allium cepa. Cytologia 38: 125129. 
Cheng, K. C., Nieh, H. W. Yang, C. L., Wang, I. H., Chou, I. S., and Chen, J. S. 1975. Light and electron microscopical observations on cytomixis and the study of its relation to evolution. Acta. Bot. Sin. 17: 60-69. (In Chinese. Engl. Summ., Biol. Abstr. 62 (1): 1090-1976).

Church, G. L. 1929. Meiotic phenomena in certain Gramineae II. Paniceae and Andropogoneae. Bot. Gaz. 88: $63-84$.

Cooper, D. C. 1952. The transfer of deoxyribose nucleic acid from the tapetum to the microsporocytes at the onset of meiosis. Amer. Naturalist 86: 219-229.

Datta, A. K., and Biswas, A. K. 1984. Cytomixis and a trisomic in Nigella sativa L. Cytologia 49: 437-445. de Nettancourt, D. and Grant, W. F. 1964. La Cytogénétique de Lotus (Leguminosae) III. Un cas de cytomixie dans un hybride interspécifique. Cytologia 29: 191-195.

Gates, R. R. 1911. Pollen formation in Oenothera gigas. Ann. Bot. 25: 909-940.

Gottschalk, W. 1970. Chromosome and nucleus migration during microsporogenesis of Pisum sativum. The Nucleus 13 (1): 1-9.

Heslop-Harrison, J. 1966. Cytoplasmic connections between angiosperm meiocytes. Ann. Bot. N. S. 30: 222230.

Kamra, O. P. 1960. Chromatin extrusion and cytomixis in pollen mother cells of Hordeum. Hereditas (Lund) 46: $592-600$.

Körnicke, M. 1901. Über Ortsveränderung von Zellkärnern. S.B. Niederrhein, Ges. Natur-u. Heilkunde Bonn. A. 14-25.

Mantu De and Sharma, A. K. 1983. Cytomixis in pollen mother cells of an apomictic ornamental E. vatamia divaricata (Linn.) Alston. Cytologia 48: 201-207.

Morisset, P. 1978. Cytomixis in pollen mother cells of Ononis (Leguminosae). Can. J. Genet. Cytol. 20: 383-388.

Narain, P. 1979. Cytomixis in pollen mother cells of Hemerocallis Linn. Curr. Sci. 48: 996-998.

Omara, M. K. 1976. Cytomixis in Lolium perenne. Chromosoma 56: 267-271.

Salesses, G. 1970. Sur Le phénoméne de cytomixie chez des hybrides triploids de prunier. Conséquences génétiques possibles. Ann. Amélior. Plant. 20: 383-388.

Sarvella, P. 1958. Cytomixis and the loss of chromosomes in meiotic and somatic cells of Gossypium. Cytologia 23: $14-24$.

Semyarkhina, S. Ya. and Kuptsou, M. S. 1974. Cytomixis in various form of sugarbeet. Vests I AN BSSR. Ser. biyal. 4: 43-47.

Takats, S. T. 1959, Chromatin extrusion and DNA transfer during microsporogenesis. Chromosoma 10: $430-453$.

Whelan, E. D. P. 1974, Discontinuities in the callose wall, intermeiocyte connections and cytomixis in angiosperm meiocytes. Can. J. Bot. 52: 1219-1224.

Woodworth, R. H. 1931. Cytomixis. J. Arnold Arbor., Harvard Univ. 12: 23-25. 